\title{
Airway Management in Arrhinia: A Case Report and Literature Review
}

\author{
Erika Celis-Aguilar ${ }^{1}$, Sergio Verdiales ${ }^{2}$, Ivonne Leon-Leyva ${ }^{3}$, Roberto Miranda-Maciel ${ }^{4}$
}

\begin{abstract}
Aim: To describe optimal airway management in arrhinia.

Background: Arrhinia is the congenital absence of the external nose, nasal cavities, and olfactory bulb, and this congenital anomaly is extremely rare. In newborns with this anomaly, airway management is urgent and crucial. There is no consensus on the airway management of these patients. Case description: A 22-year-old female visited our unit due to blindness and purulent discharge in the right eye of 5 years of evolution. She had arrhinia and was treated with an emergent tracheotomy at birth. Currently, she has purulent lacrimal ducts, leukoma in the right eye, hypertelorism, presence of nasofacial scar, absence of incisors, and neck with tracheocutaneous fistula. She had a previous history of six nasal reconstructive surgeries. She breathed through her mouth and tracheocutaneous fistula. She denied any airway difficulty.

Discussion: We described an adult case with arrhinia. She breathed effortlessly through a tracheocutaneous fistula, and as a newborn a tracheotomy was necessary. An airway management consensus in arrhinia has not been described. We describe a thorough literature review on arrhinia and airway management.

Conclusion: Arrhinia is a congenital malformation that carries the risk of respiratory difficulty. These patients require a multidisciplinary team to manage the newborn and choosing the appropriate alternative for securing the airway. Treatments described are orotracheal intubation, oropharyngeal tube, nasal reconstruction, and tracheotomy in patients who do not develop oral breathing. Tracheotomy is a definitive treatment in these patients.

Clinical significance: There are various treatments for airway management of arrhinia. Clinicians should be aware of these treatment options. Keywords: Airway management, Arrhinia, Nose diseases.

Clinical Rhinology An International Journal (2018): 10.5005/jp-journals-10013-1345
\end{abstract}

\section{BACKGROUND}

The human nose is the most prominent and characteristic facial feature, it is the initial part of the respiratory tract and the receptor organ of the sense of smell. ${ }^{1}$ Arrhinia is the congenital absence of the external nose, nasal cavities, and olfactory bulb. ${ }^{2}$ It is an extremely rare congenital malformation whose etiology remains unknown; ${ }^{3}$ it is frequently associated with other somatic or craniofacial anomalies with varying degrees of severity and high degree of mortality. ${ }^{4,5}$ For evaluation it is required to perform a computed tomography (CT) scan, magnetic resonance imaging, X-rays of the chest and abdomen, and karyotype to evaluate the commitment of organs and systems. ${ }^{6}$ The absence of nose causes severe problems in breathing and feeding of the newborn, and in some of the reported cases, it was necessary to perform a tracheotomy. Until today, there is still no consensus on the management of the airway in patients with arrhinia. ${ }^{3-5,7}$

\section{Case Description}

This case is about a 22-year-old female who came to our unit due to blindness and purulent discharge in the right eye of 5 years of evolution. The patient had no history of familiar congenital malformations, has a genetic load for diabetes mellitus, with a history of six facial surgical procedures for external and internal reconstruction of the nose. At the time of birth, an emergency tracheotomy was performed.

Physical examination revealed purulent lacrimal ducts, leukoma in the right eye, hypertelorism, absence of nose and presence of nasofacial scar, absence of incisors, grade II tonsils, and neck
${ }^{1-3}$ Department of Otolaryngology, Universidad Autonoma de Sinaloa CIDOCS, Culiacan Rosales, Sinaloa, Mexico

${ }^{4}$ Department of Internal Medicine, Universidad Autonoma de Sinaloa CIDOCS, Culiacan Rosales, Sinaloa, Mexico

Corresponding Author: Erika Celis-Aguilar, Department of Otolaryngology, Universidad Autonoma de Sinaloa CIDOCS, Culiacan Rosales, Sinaloa, Mexico, Phone: +52 6671023474, e-mail: erikacelis@ hotmail.com

How to cite this article: Celis-Aguilar E, Verdiales S, Leon-Leyva I, et al. Airway Management in Arrhinia: A Case Report and Literature Review. Clin Rhinol An Int J 2018;11(2 and 3):61-64.

Source of support: Nil

Conflict of interest: None

with tracheocutaneous fistula. A flexible laryngoscopy video was performed in which bilateral choanal atresia and presence of intracoanal septum, the upper and ogival palate, are observed. No respiratory difficulty was reported by the patient (Fig. 1).

Computed tomography was performed (Fig. 2), showing congenital absence of nasal structure, hypoplasia of the middle facial third with bilateral choanal atresia, complete absence of paranasal sinuses, palatal bone atresia with high and arched oral cavity roof, and absence of lachrymal ducts. Right dacryocystectomy was performed to resolve dacryocystitis without improvement.

\section{Discussion}

Arrhinia is an extremely rare malformation that has both physical and psychological repercussions. The embryological development 


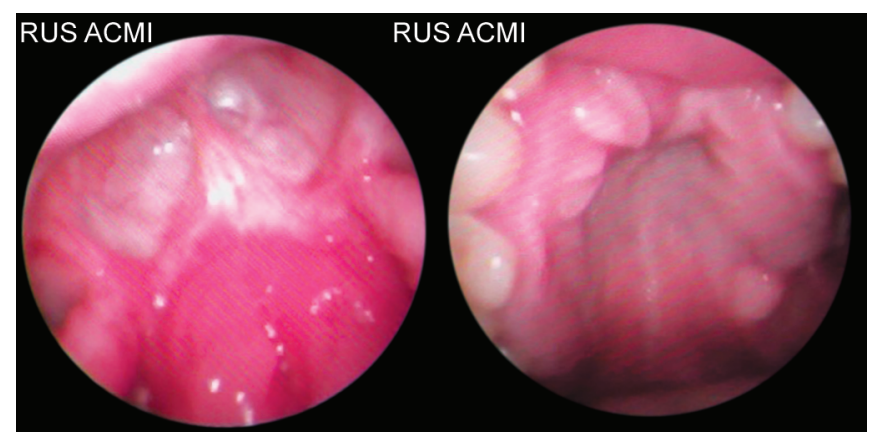

Fig. 1: Video endoscopy shows bilateral choanal atresia. Absence of nasal passages

of the nose occurs between the third and the eight week of intrauterine life; ${ }^{8}$ the formation of the face is given by the migration of cells of the neural crest from the medial and lateral nasal processes, both derived from the frontonasal process. ${ }^{9}$ Losee et al. classified nasal congenital malformations into four different types: ${ }^{10}$

Type I: Hypoplasia and atrophy

Type II: Hypertrophy and duplications

Type III: Clefs (indentations), and

Type IV: Neoplasms and vascular abnormalities.

Aberrations on chromosome 9 have been reported in the literature as inversion or trisomy. ${ }^{11}$ Nevertheless, there are some others cases where the karyotype was normal. ${ }^{3}$ Arrhinia is commonly associated with other malformations, and in our case, no other disease or malformation was found.

Since this is a very rare malformation, it is difficult to establish an incidence; some authors refer to approximately 45 cases described in the literature. ${ }^{11}$

\section{Diagnosis}

In the past, the prenatal diagnosis of patients with arrhinia was extremely complicated; however, in the recent years, due to advances in ultrasound, there have been more prenatal diagnoses. ${ }^{12,13}$ Cusik et al. were the first to document the diagnosis of arrhinia by ultrasound in 2000,12 later Majewski et al. in 2007 reported a case of total arrhinia in a patient who was in the second trimester of pregnancy. ${ }^{13}$

The evaluation of these patients consists of $\mathrm{CT}$; in our case, it was found congenital absence of nose with left rudimentary nasal structure, hypoplasia of the middle facial third with bilateral atresia of choanal, complete absence of paranasal sinuses, total absence of palatal bone with high, and arched roof of mouth and absence of lachrymal ducts. ${ }^{6,12}$ It is also advisable to perform a magnetic resonance imaging of the skull to rule out alterations in the central nervous system. ${ }^{10}$

\section{Treatment}

The neonatal patient is a mandatory nasal breather due to which most of them present respiratory distress with cyanosis at birth. ${ }^{1}$ Interestingly, most of the patients reported thus far were not tracheostomized, indicating that the congenital absence of nose is compatible with life and that the neonates apparently adapt for oral feeding and breathing over time; ${ }^{3,6}$ however, in patients where adaptation was not prompt or who required prolonged respiratory support, a tracheotomy was performed. ${ }^{3,5}$

In 1931, Blair and Brown documented with photographs the first case of reconstruction of choana and external nose with good

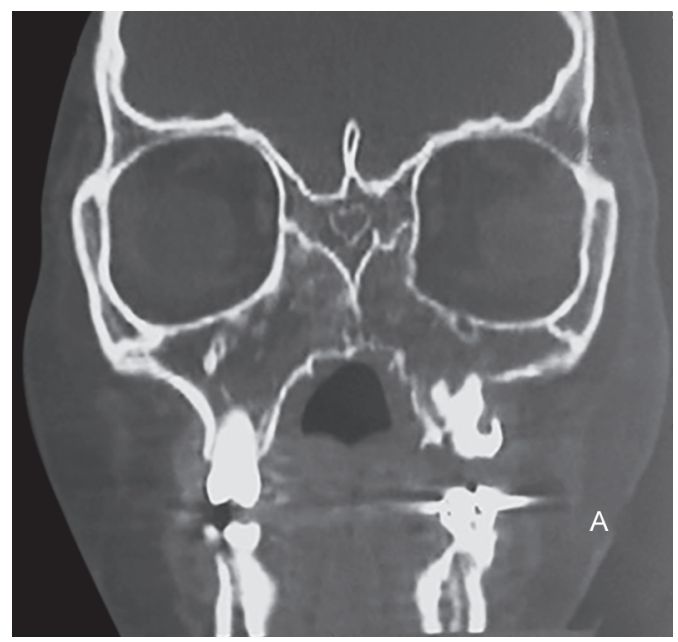

Fig. 2: Computed tomography scan (bone window) with hypoplasia of middle third of face and absence of paranasal sinuses, nasal fossa, and choana

results. At present, the surgical approach of these patients is very complex, and a multidisciplinary approach is needed that includes otorrhinolaryngological care, plastic surgery, neurosurgery, and pediatrics. Reconstruction procedures are a challenge, and there is still controversy regarding the technique and when it should be initiated.

Table 1 presents a literature review of reports of arrhinia cases in the literature. A systematic search of articles referring to this pathology was carried out, and 16 cases published in the medical literature were analyzed from 1989 to 2016, with a follow-up of 30 days to 18 years. We excluded some publications in which the follow-up was null or not significant.

A total of 16 cases with arrhinia are described, mostly born by normal pregnancy evolution (except for one case of nephrolithiasis during pregnancy and another of steroid intake as prophylaxis of premature birth); also described are patients who have no family history of congenital malformations. It was observed that treatment was personalized and varies depending on the degree of malformation, presentation, and clinical manifestations of each patient and also the surgical experience by the medical team in charge of the case. Although it is documented that neonatal patients are oral breathers per excellence and adapt to breathing and feeding through their mouth, it is common to provide respiratory support by placing an oropharyngeal probe or by performing a tracheotomy in patients with frank breathing difficulties. ${ }^{3,5,7}$ It also facilitates feeding by orogastric tube, while the patient adapts to their condition. ${ }^{14,15}$ Severe respiratory difficulty has been described previously. ${ }^{16}$

Some authors suggest that reconstruction should be done at preschool because of the psychological impact on both the parents and the patient. In our case, the patient underwent six surgical procedures for external and internal reconstruction in another hospital unit without success.

Cole et al. ${ }^{9}$ in 1989 reported the reconstruction of nasal passage with sublabial, transpalatal, and percutaneous approach with dilatation at home. In 2014, Prada et al. ${ }^{17}$ performed it with LeFort III technique and choanal aperture. Brusati et al. reported external nasal reconstruction with autologous costal graft and performed external nasal reconstruction with placement of a 
Table 1: Literature review on arrhinia cases and airway management

\begin{tabular}{|c|c|c|c|c|c|}
\hline Author, year & Patient data & Clinical presentation & Treatment & Follow-up & Result \\
\hline $\begin{array}{l}\text { Cole R, Meyer C, } \\
\text { Bratcher G (1989) }\end{array}$ & $\begin{array}{l}\text { Female of } 4 \text { days of } \\
\text { age* }^{*}\end{array}$ & $\begin{array}{l}\text { Total arrhinia. Presence } \\
\text { of cartilaginous button } \\
\text { of } 4 \mathrm{~mm}\end{array}$ & $\begin{array}{l}\text { Nasal passage } \\
\text { reconstruction with } \\
\text { sublabial, transpalatal } \\
\text { and percutaneous } \\
\text { approach. Dilation at } \\
\text { home }\end{array}$ & 9 months & $\begin{array}{l}\text { Immediate adequate } \\
\text { oral breathing } \\
\text { after surgery, normal } \\
\text { feeding. Good results } \\
\text { after } 9 \text { months }\end{array}$ \\
\hline $\begin{array}{l}\text { Weinberg A, } \\
\text { Neuman A, Benmeir } \\
\text { P, et al. }(1991)^{16}\end{array}$ & $\begin{array}{l}\text { Female of one } \\
\text { month of age* }\end{array}$ & $\begin{array}{l}\text { Arrhinia, moderate } \\
\text { respiratory difficulty, } \\
\text { right microphthalmia, } \\
\text { left anophthalmia }\end{array}$ & $\begin{array}{l}\text { Nasopharyngeal tube, } \\
\text { orogastric tube }\end{array}$ & 18 months & $\begin{array}{l}\text { Obstruction of the } \\
\text { nasopharyngeal tube, } \\
\text { due to secretions, } \\
\text { was changed twice. } \\
\text { Normal psychomotor } \\
\text { development }\end{array}$ \\
\hline $\begin{array}{l}\text { Mühlbauer W, } \\
\text { Schmidt A, Fairley J } \\
(1992)^{15}\end{array}$ & $\begin{array}{l}\text { Female, newborn } \\
\text { at full term, mother } \\
\text { attended with } \\
\text { nephrolithiasis } \\
\text { during pregnancy }\end{array}$ & Arrhinia & $\begin{array}{l}\text { Oro and nasopharyngeal } \\
\text { tube. Early simultaneous } \\
\text { reconstruction of nasal } \\
\text { cavity and external nose }\end{array}$ & 3 years & Stable nasal cavities \\
\hline \multirow[t]{4}{*}{ Meyer R (1995) ${ }^{19}$} & \multirow[t]{4}{*}{$\begin{array}{l}\text { Male newborn at } \\
\text { term* }\end{array}$} & \multirow[t]{4}{*}{$\begin{array}{l}\text { Arrhinia, respiratory } \\
\text { distress cyanosis, } \\
\text { seizures }\end{array}$} & $\begin{array}{l}\text { At birth: Orotracheal } \\
\text { intubation and mechani- } \\
\text { cal ventilation. Orogas- } \\
\text { tric tube }\end{array}$ & \multirow[t]{4}{*}{1 year } & \multirow[t]{4}{*}{$\begin{array}{l}\text { Silicon tubes were } \\
\text { used. The extraction } \\
\text { is planned in a year }\end{array}$} \\
\hline & & & $\begin{array}{l}30 \text { days: Construction of } \\
\text { nasal passage }\end{array}$ & & \\
\hline & & & $\begin{array}{l}\text { Phase 1: reconstruction } \\
\text { of external nose and } \\
\text { septum }\end{array}$ & & \\
\hline & & & $\begin{array}{l}\text { Phase 2: reconstruction } \\
\text { of internal nose }\end{array}$ & & \\
\hline $\begin{array}{l}\text { Olsen E, Gjelland } \\
\text { K, Reigstad H, } \\
\text { Rosendahl K }(2001)^{6}\end{array}$ & $\begin{array}{l}\text { Newborn } \\
\text { female, only } \\
\text { polyhydramnios } \\
\text { during pregnancy }\end{array}$ & $\begin{array}{l}\text { Arrhinia, high arc palate, } \\
\text { hypertelorism, bilateral } \\
\text { coloboma, chronic } \\
\text { dacryocystitis }\end{array}$ & $\begin{array}{l}\text { Oropharyngeal } \\
\text { intubation, orogastric } \\
\text { tube, antibiotics and } \\
\text { therapy }\end{array}$ & $\begin{array}{l}\text { No surgery was } \\
\text { performed, follow- } \\
\text { up for } 8 \text { months }\end{array}$ & Oropharyngeal tube \\
\hline $\begin{array}{l}\text { Feledy J.A, et al. } \\
(2003)^{7}\end{array}$ & $\begin{array}{l}\text { Newborn male } \\
\text { patient, uneventful } \\
\text { pregnancy* }\end{array}$ & $\begin{array}{l}\text { Total arrhinia, high arc } \\
\text { palate, hypertelorism, } \\
\text { inverse cantus }\end{array}$ & $\begin{array}{l}\text { At birth: tracheostomy, } \\
\text { gastrostomy } \\
4 \text { years of age: Le Fort II }\end{array}$ & NA & $\begin{array}{l}\text { New bone formation } \\
\text { on pterygoid } \\
\text { anatomical region }\end{array}$ \\
\hline $\begin{array}{l}\text { Neeraj N. Mathur, N. } \\
\text { Dubey }(2005)^{3}\end{array}$ & Male newborn* & $\begin{array}{l}\text { Total arrhinia, breathing } \\
\text { distress, left } \\
\text { coloboma }\end{array}$ & $\begin{array}{l}\text { Endotracheal intubation, } \\
\text { tracheostomy }\end{array}$ & NA & Tracheostomy \\
\hline $\begin{array}{l}\text { Goyal A, Agrawal V, } \\
\text { Raina VK, Sharma D } \\
(2008)^{11}\end{array}$ & $\begin{array}{l}\text { Full-term male } \\
\text { newborn* }\end{array}$ & $\begin{array}{l}\text { Absence of external } \\
\text { nose, respiratory } \\
\text { distress, hypertelorism, } \\
\text { microphthalmia, } \\
\text { microcephaly, } \\
\text { craniosynostosis }\end{array}$ & $\begin{array}{l}\text { Endotracheal intubation, } \\
\text { orogastric suctioning, } \\
\text { nasopharyngeal tube } \\
\text { inserted of } 4 \mathrm{Fr}\end{array}$ & 1 month & $\begin{array}{l}\text { Re-stenosis at one } \\
\text { month. Patient } \\
\text { learned oral } \\
\text { breathing and oral } \\
\text { feeding with spoon }\end{array}$ \\
\hline $\begin{array}{l}\text { Brusati R, Donati V, } \\
\text { Marelli S }(2009)^{2}\end{array}$ & $\begin{array}{l}\text { Female } 6 \text { years of } \\
\text { age with brother of } \\
3 \text { years, both with } \\
\text { arrhinia }\end{array}$ & $\begin{array}{l}\text { Total arrhinia } \\
\text { Normal psychomotor } \\
\text { development } \\
\text { Diagnosis of Treacher } \\
\text { Collins. Maxillary } \\
\text { hypoplasia }\end{array}$ & $\begin{array}{l}\text { At } 6 \text { years of age: } \\
\text { Maxillary osteotomy } \\
\text { Costal autogenous graft }\end{array}$ & 12 months & $\begin{array}{l}\text { Satisfactory result } \\
\text { (airway and nasal } \\
\text { appearance) }\end{array}$ \\
\hline $\begin{array}{l}\text { Hossein Fakhraee } \\
\text { S, Nariman S, } \\
\text { Taghipour R }(2011)^{5}\end{array}$ & $\begin{array}{l}\text { Fullterm newborn } \\
\text { male* }\end{array}$ & $\begin{array}{l}\text { Arrhinia, Anophthalmia } \\
\text { Oral breathing. No other } \\
\text { anomalies }\end{array}$ & $\begin{array}{l}\text { Orotracheal intubation } \\
\text { Tracheostomy }\end{array}$ & $\begin{array}{l}30 \text { days in intensive } \\
\text { care unit }\end{array}$ & $\begin{array}{l}\text { Died from sepsis at } \\
2.5 \text { months of age }\end{array}$ \\
\hline \multirow[t]{2}{*}{$\begin{array}{l}\text { Brusati R, Colletti } \\
\text { Giacom }(2012)^{2}\end{array}$} & \multirow{2}{*}{$\begin{array}{l}\text { Male of } 12 \text { years of } \\
\text { age. He was born in } \\
\text { Norway* }^{*}\end{array}$} & \multirow[t]{2}{*}{ Arrhinia } & $\begin{array}{l}\text { At birth: No respiratory } \\
\text { distress }\end{array}$ & \multirow[t]{2}{*}{6 months } & \multirow[t]{2}{*}{ Satisfactory } \\
\hline & & & $\begin{array}{l}\text { At } 12 \text { years: Le Fort I + } \\
\text { nasal splints }\end{array}$ & & \\
\hline
\end{tabular}




\begin{tabular}{|c|c|c|c|c|c|}
\hline Author, year & Patient data & Clinical presentation & Treatment & Follow-up & Result \\
\hline \multirow[t]{2}{*}{$\begin{array}{l}\text { Prada JR, Mendoza } \\
\text { MB }(2014)^{17}\end{array}$} & $\begin{array}{l}\text { 1: Male } 1 \text { year and a } \\
\text { half of age* }\end{array}$ & $\begin{array}{l}\text { 1: Right hemiarrhinia, } \\
\text { high arc palate }\end{array}$ & Choanal & 1: 18 years & $\begin{array}{l}\text { 1: nasal } \\
\text { reconstruction }\end{array}$ \\
\hline & $\begin{array}{l}\text { 2: Female, } 8 \text { years } \\
\text { of age* }\end{array}$ & $\begin{array}{l}\text { 2: Total arrhinia, } \\
\text { microphthalmia, } \\
\text { telecanthus }\end{array}$ & $\begin{array}{l}\text { Reconstruction, } \\
\text { osteotomy LeFort III }\end{array}$ & 2: 2 months & $\begin{array}{l}\text { 2: Nasal external } \\
\text { reconstruction }\end{array}$ \\
\hline $\begin{array}{l}\text { Navas-AparicioMdC, } \\
\text { Mora-Mesén C } \\
(2016)^{4}\end{array}$ & Female patient & $\begin{array}{l}\text { Arrhinia and bilateral } \\
\text { anophthalmia }\end{array}$ & $\begin{array}{l}\text { Orotracheal intubation } \\
\text { and tracheotomy }\end{array}$ & 12 years & $\begin{array}{l}\text { Malnutrition and } \\
\text { psychomotor delay }\end{array}$ \\
\hline $\begin{array}{l}\text { Fernandez N, Van } \\
\text { den Heever J, Sykes } \\
\text { L, et al. }(2016)^{18}\end{array}$ & $\begin{array}{l}\text { Female } 7 \text { years of } \\
\text { age }\end{array}$ & $\begin{array}{l}\text { Total arrhinia, } \\
\text { coloboma, strabismus }\end{array}$ & Nasal prosthesis & 10 years & $\begin{array}{l}\text { Surgical } \\
\text { reconstruction, LeFort } \\
\text { I and nasal prosthesis }\end{array}$ \\
\hline $\begin{array}{l}\text { Mondal U, Prasad R } \\
(2016)^{14}\end{array}$ & $\begin{array}{l}\text { Male newborn, } 38 \\
\text { gestational age* }\end{array}$ & $\begin{array}{l}\text { Arrhinia, hypertelorism, } \\
\text { bilateral microphthalmia } \\
\text { and coloboma. No } \\
\text { respiratory distress } \\
\text { but there is feeding } \\
\text { difficulty }\end{array}$ & Orogastric tube & 1 year & $\begin{array}{l}\text { Oral feeding } \\
\text { by paladal }\end{array}$ \\
\hline
\end{tabular}

NA, nonavailable. *Normal pregnancy and no family history of congenital anomalies

nasal prosthesis with good results. ${ }^{2}$ One author has reported a successful reconstruction of nasal passage with LeFort I osteotomy, dacryocystorrhinostomy, and the insertion of a silicone nasal prosthesis. ${ }^{18}$ Furthermore, Meyer et al. performed surgical creation of the nasal passage with formation of anterior septum and external nose to later perform reconstruction of the internal nose without reporting long-term results. ${ }^{19}$

\section{Clinical Significance}

There is still no consensus on airway management in patients with arrhinia. Interestingly, most patients who have undergone some type of surgical reconstruction have had satisfactory results. Our case required treatment with tracheostomy at birth, and later the patient developed oral breathing and currently also persists with breathing through a residual tracheotomy fistula. Since we present a case with probably the longest follow-up of a patient with arrhinia, 22 years of age with no respiratory symptoms, tracheotomy can be a good alternative as a definitive treatment of airway management in arrhinia patients with minimal complications.

\section{Conclusion}

Arrhinia is a congenital malformation that carries the risk of respiratory difficulty. These patients require a multidisciplinary team to manage the newborn and choose appropriate alternative for securing the airway. Possible treatments options are orotracheal intubation, oropharyngeal tube, nasal reconstruction, and tracheotomy in patients who do not develop oral breathing. Tracheotomy is a definitive treatment in these patients.

\section{References}

1. Pérez-silva O. Arrinia: ausencia congenital total de la nariz. Medicina 2010;32:33-46.

2. Brusati R, Donati V, Marelli S, et al. Management of a case of arrhinia. J Indian Assoc Pediatr Surg 2008;67:206-210.

3. Mathur N, Dubey N, Kumar S, et al. Arrhinia. Int J Pediatr Otorhinolaryngol 2005;69(1):97-99. DOI: 10.1016/j.ijporl.2004.07.016.

4. Navas-Aparicio M, Mora-Mesen C. Agenesia nasal y otras malformaciones faciales: reporte de de un caso de anomalía congénita y revisión de literatura. Acta Otorrinolaringol Esp 2016(5):Disponible Online: http://dx.doi.org/10.1016/j.otorri.2016.07.007.
5. Hossein S, Narirman S, Taghipour R. Congenital arhinia: case report of a congenital anomaly. Arch Iran Med 2011;14:335-356.

6. Olsen $\mathrm{O}$, Gjelland K, Reigstad H, et al. Congenital absence of the nose: a case report and literature review. Pediatr Radiol 2001;31(4):225-232. DOI: $10.1007 / \mathrm{s} 002470000419$.

7. Feledy J, Goodman C, Taylor T, et al. Vertical facial distraction in the treatment of arrhinia. Plast Recontr Surg 2004;113(7):2061-2066. DOI: 10.1097/01.prs.0000122218.78595.97.

8. Nishimura Y. Embryological study of nasal cavity development in human embryos whit reference to congenital nostril atresia. Acta Anat 1993;147(3):140-144. DOI: 10.1159/000147494.

9. Cole R, Meyer C, Bratcher G. Congenital absence of the nose: a case report. Int J Pediatr Otorhinolaryn 1989;17(2):171-177. DOI: 10.1016/0165-5876(89)90092-x.

10. Losee JE, Kirschner RE, Whitaker LA, et al. Congenital nasal anomalies: a classification scheme. Plast Reconstr Surg 2004;113(2):676-689. DOI: 10.1097/01.PRS.0000101540.32533.EC.

11. Goyal A, Agrawal V, Raina V, et al. Congenital arhinia: a rare case. J Indian Assoc Pediatr Surg 2008;13(4):153-154. DOI: 10.4103/09719261.44771.

12. Cusik W, Sullivan C, Rojas B, et al. Prenatal diagnosis of total arhinia. Ultrasound Obstet Gynecol 2000;15(3):258-261. DOI: 10.1046/j.14690705.2000.00081.x.

13. Majewski S, Donnenfeld A, Kuhlman K, et al. Second trimester prenatal diagnosis of total arrhinia. J Ultrasound Med 2007;26(3):391-395. DOI: 10.7863/jum.2007.26.3.391.

14. Uttam M, Prasad R. Congenital arhinia: a rare case report and review. Indian J Otolaryngol Head Neck Surg 2016;68(4):537-539. DOI: 10.1007/s12070-016-1009-x.

15. Mühlbauer W, Schmidt A, Fairley J. Simultaneous construction of an internal and external nose in an infant with arhinia. Plast Reconstr Surg 1993;91(4):720-725. DOI: 10.1097/00006534-199304000-00027.

16. Weinberg $A$, Neuman $A$, Benmeir $P$, et al. A rare case of arhinia with severe airway obstruction: case report and review of the literature. Plast Reconstr Surg 1991;91(1):146-149. DOI: 10.1097/00006534199301000-00024.

17. Prada J, Mendoza M. Use of distraction osteogenesis in arrhinia. J Craniofac Surg 2014;24(3):888-891. DOI: 10.1097/ SCS.0000000000000518.

18. Fernandes N, Van den Heerver J, Sykes L, et al. Nasal reconstruction of a patient with complete congenital arhinia: a clinical report. J Prosthet Dent 2016;116(6):924-927. DOI: 10.1016/j.prosdent.2016.04.014.

19. Meyer R. Total external and internal construction in arhinia. Plast Reconstr Surg 1997;99(2):534-542. DOI: 10.1097/00006534199702000-00036. 